\title{
SISTEM TEMU KEMBALI CITRA DENGAN HISTOGRAM FUZZY DAN CHI-SQUARE DISTANCE
}

\author{
${ }^{1}$ Raditya Hendrawan, ${ }^{2}$ Dwi Puspitasari \\ ${ }^{1,2}$ Program Studi Teknik Informatika, Jurusan Teknologi Informasi, Politeknik Negeri Malang \\ ${ }^{1}$ radityahendraw@gmail.com, ${ }^{2}$ dwi_puspitasari@polinema.ac.id
}

\begin{abstract}
Abstrak
Temu kembali citra berbasis query teks telah jamak digunakan di dalam suatu sistem temu kembali citra. Namun temu kembali dengan query teks tidak efektif apabila deskripsi citra tidak mengambarkan konten yang terkandung dalam citra. Dari latar belakang tersebut diajukan sebuah solusi berupa suatu sistem temu kembali citra berwarna menggunakan metode histogram warna fuzzy dan chi-square distance. Sistem ini menggunakan konten berupa citra sebagai query sebagai acuan temu kembali citra yang mirip dari segi komposisi warna. Histogram warna fuzzy didapatkan dengan mengelompokkan warna dengan pendekatan fuzzy. Kemudian histogram warna fuzzy dari citra query dan citra koleksi melalui uji kemiripan dengan formula chi-square distance. Sistem yang diuji mampu menemukan kembali citra yang sama serta mampu menemukan citra yang mirip dalam koleksi citra homogen dan heterogen dengan kesesuaian terhadap pengamatan manusia masing-masing sebesar $89,5 \%$ dan $78 \%$.
\end{abstract}

Kata Kunci : Temu kembali citra, histogram warna fuzzy, chi-square distance

\section{Pendahuluan}

Teknologi media penyimpanan yang semakin mendukung tersimpannya data citra digital dengan besar di dalam media penyimpanan lokal maupun dalam server. Penyimpanan citra digital dalam jumlah besar ini memberikan kesulitan dalam pengelolaannya khususnya pada pecarian atau temu kembali(retrieval). Sistem pencarian pada umumnya berbasis teks dengan merujuk pada nama file citra. Namun pencarian sulit jika sebagian besar nama file citra dalam database tidak mewakili gambar yang terkandung dalam citra tersebut seperti jika citra tersebut berasal dari kamera digital.

Salah satu metode pencarian citra adalah temu kembali citra berbasis konten (Content Based Image Rerieval). Dengan metode ini pecarian citra dilakukan dengan mecocokkan atribut-atribut yang terkandung dalam citra tersebut. Salah satu atribut yang dapat digunakan dalam temu kembali citra adalah atribut warna.

Metode yang digunakaan untuk merepresentasikan atribut warna adalah Histogram warna. Histogram adalah metode statistik, yang menggambarkan persebaran warna dalam sebuah citra. Kelemahan dari histogram warna konvensional adalah metode ini tidak mempertimbangkan persamaan warna pada bin yang berbeda dan perbedaan pada bin yang sama(Han J \& Ma KK 2002).

Untuk kelemahan histogram warna konvensional dalam persepsi kesamaan warna pada bin maka berkembang suatu metode lain yang disebut histogram warna fuzzy. Histogram warna fuzzy adalah salah satu cara yang dapat digunakan untuk mengurangi bin warna. Histogram warna fuzzy memanfaatkan logika fuzzy serta sistem inferensi fuzzy dalam implementasinya. Sistem inferensi fuzzy berperan dalam penentuan golongan bin warna tiap pixel.

Untuk membandingkan persamaan dari citra dibutuhkan suatu alat ukur yang membandingkan histogram. Terdapat banyak metode yang telah digunakan untuk membandingkan histogram, salah satunya adalah Chi-Square distance. Chi-Square distance biasa digunakan pada ilmu statistika sebagai metode untuk uji kecocokan (goodest of fit test) antara frekuensi sampel teramati dengan frekuensi sampel harapan yang dalam penelitian ini digunakan untuk histogram query dan histogram citra dalam database.

Dari uraian di atas, maka pada penelitian ini dikembangkan suatu sistem temu kembali citra berwarna menggunakan histogram fuzzy dan chisquare distance. Sistem mampu menerima masukan (query) berupa citra berwarna yang ingin dicari dan menampilkan sejumlah citra yang memiliki kemiripan komposisi warna dengan citra masukan. Diharapakan sistem ini akan membantu pengelolaan citra dalam jumlah besar dalam hal temu kembali atau pencarian.

\section{Landasan Teori}

2.1 Citra Digital

Citra Digital merujuk pada pemrosesan gambar 2 dimensi menggunakan komputer. Dalam konteks 
yang lebih luas, pengolahan citra digital mengacu pada pemrosesan setiap data 2 dimensi. Citra digital merupakan sebuah larik (array) yang berisi nilai-nilai real maupun komplek yang direpresentasikan dengan deretan bit tertentu (Putra,2010).

Suatu citra didefinisikan sebagai fungsi $f(x, y)$ berukuran $\mathrm{M}$ baris dan $\mathrm{N}$ kolom, dengan $\mathrm{x}$ dan $\mathrm{y}$ adalah koordinat spasial, dan amplitudo $f$ dan titik koordinat $(x, y)$ dinamakan intensitas atau tingkat keabuan dari citra pada titik tersebut. Apabila nilai $\mathrm{x}, \mathrm{y}$, dan nilai amplitudo $f$ secara keseluruhan berhingga (finite) dan bernilai diskrit maka dikatakan bahwa citra tersebut adalah citra digital. Gambar 1 menunjukkan posisi koordinat citra digital.

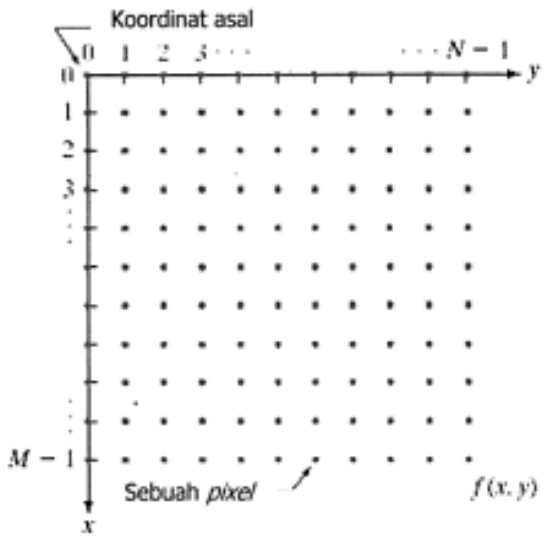

Gambar 1 Koordinat citra digital

Citra digital dapat ditulis dalam bentuk matrik sebagai berikut.

$$
f(x, y)=\left[\begin{array}{cccc}
f(0,0) & f(0,1) & \cdots & f(0, N-1) \\
f(1,0) & f(1,1) & \cdots & f(1, N-1) \\
\vdots & \vdots & & \vdots \\
f(M-1,0) & f(M-1,1) & \cdots & f(M-1, N-1)
\end{array}\right](1)
$$

Nilai pada suatu irisan baris dan kolom (pada posisi $\mathrm{x}, \mathrm{y}$ ) disebut dengan picture elements, image elements, pels, atau pixels. Istilah terakhir (pixel) paling sering digunakan pada citra digital.

\subsection{Warna}

Warna sebagai persepsi yang ditangkap sistem visual terhadap panjang gelombang cahaya yang dipantulkan oleh objek. Secara fisik warna adalah reaksi otak terhadap stimulasi visual tertentu (Ford dan Roberts,2008). Pada retina mata, warna dibentuk berdasrakan tiga unsur cahaya yaitu merah, hijau dan biru, biasa disebut tri-chromatic, melalui gabungan ketiga cahaya tersebut, otak menerjemahkan berbagai macam warna.

Sistem penggunaan tiga unsur cahaya dalam merepresentasikan warna secara fisik diadopsi juga dalam berberapa ruang warna lain di bidang teknologi komputer. Model warna adalah model standard untuk mendefinisikan dan menampilkan warna pada komputer, televisi dan perangkat elektronik lain.
Beberapa model warna yang digunakan sekarang antara lain :

Tabel 2.1 Tabel Model Warna

\begin{tabular}{|l|l|}
\hline Model Warna & Deskripsi \\
\hline RGB & $\begin{array}{l}\text { Red(Merah), Green(Hijau), dan } \\
\text { Blue(Biru), model warna pokok } \\
\text { adaptif yang digunakan pada } \\
\text { sistem display }\end{array}$ \\
\hline CMY(K) & $\begin{array}{l}\text { Cyan, Magenta, Yellow (dan } \\
\text { Hitam). Sebuah model warna } \\
\text { substraktif yang digunakan } \\
\text { pada mesin printer. }\end{array}$ \\
\hline YcbCr & $\begin{array}{l}\text { Luminasi (Y) dan Dua } \\
\text { Komponen kromasiti (Cb dan } \\
\text { Cr). Digunakan dalam siaran } \\
\text { geombang televisi. }\end{array}$ \\
\hline HIS (HSL) & $\begin{array}{l}\text { Hue, Saturasi dan intensitas. } \\
\text { Berdasarkan persepsi manusia } \\
\text { terhadap warna. }\end{array}$ \\
\hline CIE L*a*b & $\begin{array}{l}\text { L untuk luminance (kecerahan) } \\
\text { dan a, b untuk dua komponen } \\
\text { warna yang berbeda. Model } \\
\text { warna yang didasarkan pada } \\
\text { representasi konseptual } \\
\text { manusia. }\end{array}$ \\
\hline
\end{tabular}

Atribut warna inilah yang menjadi parameter pada penelitian ini. Kesamaan komposisi warna menjadi acuan penghitungan kemiripan suatu citra query dengan citra dalam database.

Pada penelitian ini warna RGB pada citra dikonversi menjadi model HSL. Proses konversi model warna RGB ke model warna HSL dilakukan untuk mempermudah ektraksi, karena model warna HSL hanya menggunakan satu parameter untuk menentukan warna yaitu $\mathrm{H}($ Hue $)$.

\subsection{Konsep Temu Kembali Citra}

Temu kembali citra bebasis konten (Content Base Image Retrieval) adalah suatu teknik untuk mencari citra dari basis data citra yang besar menggunakan konten visual (atribut/fitur) citra menurut kriteria yang diinginkan. Temu kembali citra berbasis konten mulai dikenal sejak tahun 1990-an, namun sejarah temu kembali citra dimulai pada tahun 1970-an.

Proses dalam sistem temu kembali citra berbasis konten terdapat dalam dua tahapan, yaitu:

1. Ektraksi atribut

Atribut yang diperlukan dalam citra, diekstrak menggunakan metode tertentu. Atribut bisa berupa warna, tekstur, bentuk dan lainnya.

2. Pencocokan

Atribut citra kueri dan atribut masing-masing citra pada basis data dicocokkan satu-persatu. Pencocokan dilakukan dengan membandingkan kedua buah atribut. Jika selisih perbedaan sedikit, maka kedua citra dikatakan sama. 


\subsection{Histogram Warna Fuzzy}

Histogram warna konvensional menggolongkan warna-warna ke dalam banyak bin dan bin warna yang bertetangga memiliki perbedaan yang tidak signifikan. Perbedaan yang tidak signifikan ini namun berbeda bin ini menimbulkan permasalahan seperti adanya noise pada suatu citra menimbulkan perbedaan golongan bin. Permasalahan seperti ini dapat dikurangi dengan mengelompokkan warna yang hampir sama melalui sistem inferensi fuzzy. Histogram hasil sistem inferensi ini disebut histogram warna fuzzy. Sistem inferensi fuzzy berperan dalam penentuan golongan bin warna tiap pixel. Pada histogram warna fuzzy satu warna dapat masuk ke dalam lebih dari satu bin dengan derajat keanggotaan yang berbeda di setiap bin-nya.Untuk mengelompokkan warna dalam suatu bin, suatu warna akan dimasukkan ke dalam rumus keanggotaan fuzzy seperti yang terlihat pada tabel dibawah.

Tabel 1 Tabel Rumus Keanggotaan Fuzzy

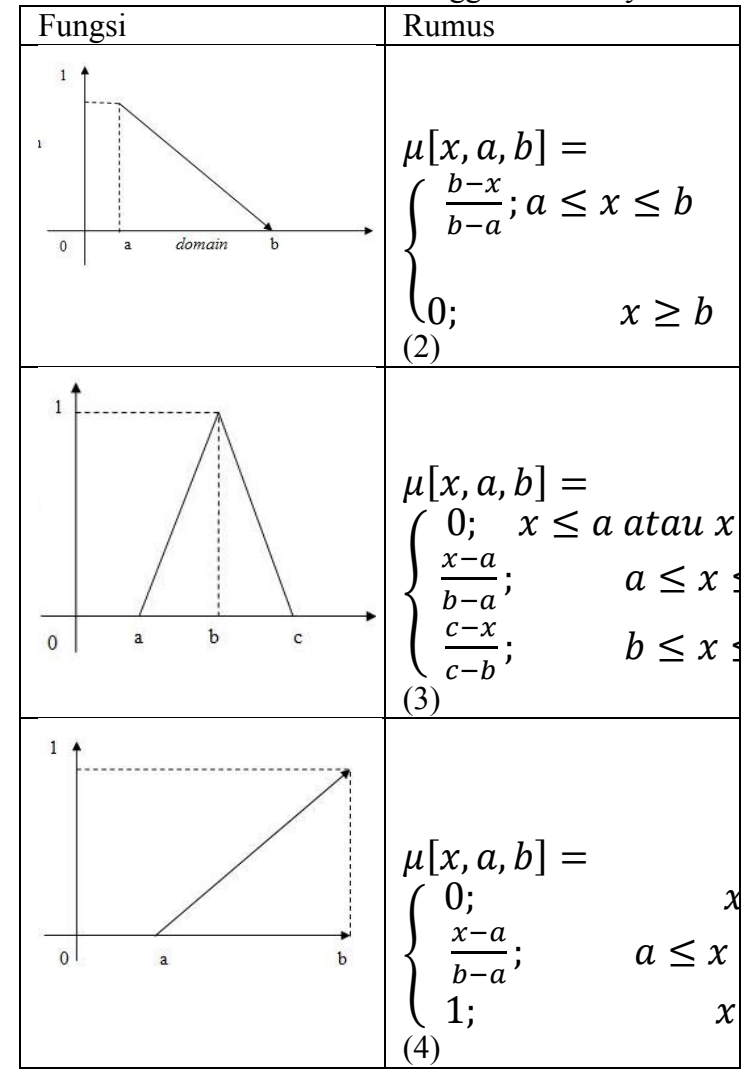

\subsection{Chi Square Distance}

Uji chi square (dilambangkan dengan " $\chi^{2 "}$ dari huruf Yunani "Chi" dilafalkan "Kai") digunakan untuk menguji dua kelompok data baik variabel independen maupun dependennya berbentuk kategorik atau dapat juga dikatakan sebagai uji proporsi untuk dua peristiwa atau lebih, sehingga datanya bersifat diskrit.

Dasar uji kai kuadrat itu sendiri adalah membandingkan perbedaan frekuensi hasil observasi
(O) dengan frekuensi yang diharapkan (E). Perbedaan tersebut meyakinkan jika harga dari chi square sama atau lebih besar dari suatu harga yang ditetapkan pada taraf signifikan tertentu (dari tabel $\chi^{2}$ ).

\section{Analisis dan Perancangan}

Pada bagian ini akan ditunjukan desain dari sistem temu kembali citra yang dibangun

\subsection{Analisis}

Dalam Sistem temu kembali citra ini memiliki dua proses utama yaitu:

1) Ekstraksi Citra

Ekstraksi merupakan pengambilan informasi dari citra yang. Penelitian ini menggunakan warna sebagai atribut atau fitur diekstraksi. Ekstraksi warna pada penelitian ini dilakukan menggunakan pendekatan fuzzy ke dalam bentuk histogram, metode ini disebut dengan histogram fuzzy. Dari histogram fuzzy tersebut akan didapatkan komposisi warna dari citra.

Proses konversi model warna RGB ke model warna HSL dilakukan untuk mempermudah ektraksi, karena model warna HSL hanya menggunakan satu parameter untuk menentukan warna yaitu $\mathrm{H}(H u e)$. Sedangkan S(Saturation) digunakan untuk mementukan kemurnian warna atau kekeruhan warna(abu-abu) dan L(Lightness) digunakan untuk menetukan tingkat percampuran warna putih dalam warna.

Untuk mengelompokkan warna. Hue dibagi menjadi 6 warna dalam fuzzy set. Berikut ini adalah Fuzzy set dari variabel Hue:

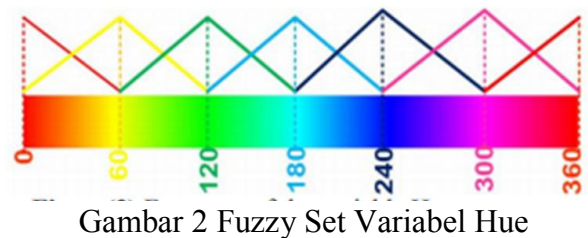

Dari fuzzy set diatas suatu warna dikelompokkan dalam suatu bin warna dengan rumus fuzzy(Tabel 1 Tabel Rumus Keanggotaan Fuzzy). Namun dari fuzzy set variable Hue diatas belum dapat mengelompokkan warna putih, hitam, dan abu-abu. Disinilah digunakan Saturation dan Lightness sebagai parameter. Dibuatlah rules sebagai berikut:

Tabel 2 Tabel Rules warna

\begin{tabular}{|l|l|}
\hline Warna & Rules \\
\hline Putih & $\mathrm{L}>95$ \\
\hline Hitam & $\mathrm{L}<=10$ dan $\mathrm{S}<25$ \\
\hline Abu-abu & $\mathrm{L}>10$ dan $\mathrm{S}<10$ \\
\hline
\end{tabular}

Akan timbul masalah jika pada uji kemiripan dibandingkan dua citra dengan ukuran yang berbeda. Hal tersebut akan menimbulkan perbedaan signifikan pada setiap citra. Maka dari itu perlu penyamaan jumlah frekuensi dari histogram warna atau dinamakan normalisasi. Normalisasi dilakukan dengan membuat presentase disribusi warna dari tiap 
bin. Sehingga setiap citra akan memiliki jumlah frekuensi pada histogram sebesar 100 .

\section{2) Uji Kemiripan}

Sedangkan pada uji kemiripan, pada penelitian ini menggunkan metode chi square distance, yang merupakan pengembangan dari chi-square test yang biasa digunakan menghitung kesesuaian suatu data. Histogram dari citra query akan dibandingkan dengan histogram citra dalam basis data hingga ditemukan jarak dari keduanya.

Rumus chi-square yang merupakan uji statistik yang biasa digunakan untuk membandingkan data yang diamati dengan data yang kita harapkan dikembanagkan menjadi chi-square distance yang menujukkan jarak kesesuaian data diamati dengan data diharapkan seperti rumus dibawah ini:

$$
C\left(p_{i}, q_{j}\right)=\frac{1}{2} \sum_{k=1}^{K} \frac{\left[h_{i}(k)-h_{j}(k)\right]^{2}}{h_{i}(k)+h_{j}(k)}
$$

Keterangan:

$\mathrm{C}=$ nilai chi square distance

$\mathrm{p}_{\mathrm{i}}=$ Citra 1

$\mathrm{q}_{\mathrm{j}}=$ Citra 2

$\mathrm{K}=$ Jumlah bin warna

$\mathrm{h}_{\mathrm{i}}(\mathrm{k})=$ Frekuensi histogram citra $1 \mathrm{ke}-\mathrm{k}$

$\mathrm{h}_{\mathrm{j}}(\mathrm{k})=$ Frekuensi histogram citra $2 \mathrm{ke}-\mathrm{k}$

Dari rumus diatas akan ditemukan suatu angka yang menunjukkan jarak kemiripan antara dua citra. Semakin mirip citra semakin mendekati 0 , sebaliknya semakin tidak mirip suatu citra jarak akan semakin besar.

Jalannya sistem temu kembali citra pada penelitian ini sendiri, terbagi lagi menjadi dua tahap.

1) Tahap pertama adalah preproses yaitu persiapan data. Tahap ini merupakan tahap persiapan, dimana citra-citra yang akan digunakan sebagai database diunggah untuk dilakukan proses ekstraksi. Kemudian hasil ekstraksi berupa histogram akan disimpan dalam database Mysql, sehingga mempercepat proses temu kembali informasi.

2) Tahap kedua adalah proses yaitu tahap dimana akan dimunculkan hasil dari temu kembali citra. Pada tahap ini citra query akan diekstraksi ke bentuk histogram fuzzy kemudian akan melalui proses uji kemiripan dengan histogram-histogram dari citra yang telah tersimpan dalam database Mysql di tahap sebelumnya.

Alur sistem sendiri digambarkan oleh gambar berikut:

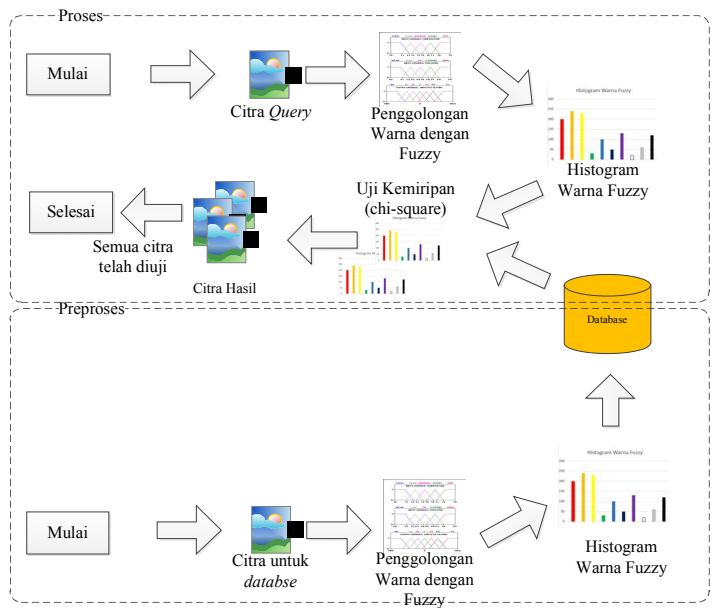

Gambar 3 Gambaran Kerja Sistem

\subsection{Perancangan Proses}

Ada dua proses utama pada sistem ini yaitu ektraksi dan uji kemiripan. Pada proses ekstraksi, masukan berupa citra digital yang berektensi atau berformat jpeg, png, maupun gif. Dengan metode fuzzy, setiap warna dikelompokkan pada bin sehingga menjadi histogram warna.

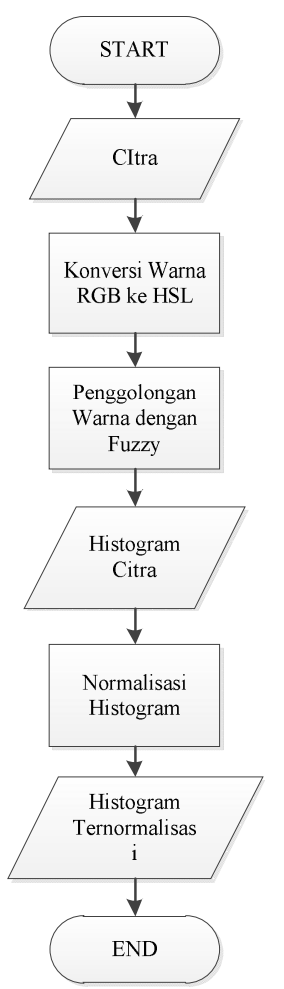

Simbol 1 Flowchart Ekstraksi

Pada proses uji kemiripan, masukan berupa histogram fuzzy dari citra query dibandingkan dengan histogram fuzzy dari citra koleksi dalamdatabase. Uji kemiripan dilakukan dengan perhitungan chi-square distance hingga didapatkan keluaran berupa angka perbedaan kedua citra. 


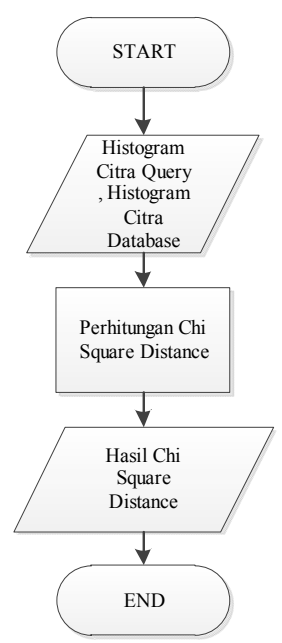

Simbol 2 Flowchart Uji Kemiripan

\section{Uji Coba dan Pembahasan}

Pengujian dilakukan

untuk menguji keakuratan dari sistem. Untuk itu dilakukan beberapa percobaan terhadap sistem dan juga survey untuk membandingkan hasil pengamatan manusia dengan hasil temu kembali dari sistem.

\subsection{Pengujian untuk Menemukan Citra yang Sama}

Pada pengujian ini dilakukan untuk mengetahu kemampuan sistem menemukan citra yang sama namun dengan perlakuan khusus pada citra query, diantaranya:

Tabel 4 Tabel Pengujian untuk Menemukan Citra

\begin{tabular}{|l|l|l|l|}
\hline No & $\begin{array}{l}\text { Perlakuan pada } \\
\text { citra query }\end{array}$ & $\begin{array}{l}\text { Hasil yang } \\
\text { diharapkan }\end{array}$ & $\begin{array}{l}\text { Hasil } \\
\text { Pengujian }\end{array}$ \\
\hline 1 & Citra query asli & $\begin{array}{l}\text { Chi square } \\
\text { distance 0 }\end{array}$ & $\begin{array}{l}\text { Sesuai } \\
\text { harapan }\end{array}$ \\
\hline 2 & $\begin{array}{l}\text { Citra query } \\
\text { diperkecil }\end{array}$ & $\begin{array}{l}\text { Chi square } \\
\text { distance } \\
\text { mendekati 0 }\end{array}$ & $\begin{array}{l}\text { Sesuai } \\
\text { harapan }\end{array}$ \\
\hline 3 & $\begin{array}{l}\text { Citra query } \\
\text { dibalik }\end{array}$ & $\begin{array}{l}\text { Chi square } \\
\text { distance } \\
\text { mendekati 0 }\end{array}$ & $\begin{array}{l}\text { Sesuai } \\
\text { harapan }\end{array}$ \\
\hline 4 & $\begin{array}{l}\text { Citra query } \\
\text { dipotong }\end{array}$ & $\begin{array}{l}\text { Chi square } \\
\text { distance } \\
\text { mendekati 0 }\end{array}$ & $\begin{array}{l}\text { Sesuai } \\
\text { harapan }\end{array}$ \\
\hline
\end{tabular}

\subsection{Pengujian untuk Menmukan Citra yang Mirip \\ Pada pengujian ini, dibutuhkan pembanding} hasil dari sistem yaitu hasil pengamatan atau intuisi manusia. Dengan begitu dapat diketahui berapa nilai kesesuaian harapan hasil temu kembali dengan hasil temu kembali yang diberikan oleh sistem.

Kesesuaian harapan dan hasil dihitung menggunakan rumus korelasi kendall tau. Koefisien Korelasi Kendall Tau sendiri memiliki range -1 hingga 1 . Koefisien 1 menunjukkan bahwa urutan
Sistem dan Responden A sama. Sedangkan koefisien -1 menunjukkan urutan yang terbalik antara urutan Sistem dan urutan Responden A.

\subsubsection{Pengujian dengan Koleksi Citra Homogen}

Pengujian dengan koleksi citra homogen(sejenis) dimaksudkan untuk mengetahui kemampuan sistem temu kembali dalam menemukan kembali citra yang benar mirip dalam koleksi citra yang sejenis.

Tabel 5 Tabel Hasil Pengujian Sistem dengan Koleksi Citra Homogen

\begin{tabular}{|c|c|c|c|c|c|}
\hline \multicolumn{6}{|c|}{ Koleksi Citra Homogen } \\
\hline \multirow[b]{2}{*}{ Query } & \multicolumn{5}{|c|}{ Rangking } \\
\hline & 1 & 2 & 3 & 4 & 5 \\
\hline & $\mathrm{D}$ & $\mathrm{E}$ & B & $\mathrm{C}$ & A \\
\hline & & \& & & 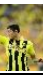 & 3 \\
\hline
\end{tabular}

Tabel 6 Tabel Hasil Responden dengan Koleksi Citra Homogen

\begin{tabular}{|l|l|l|l|l|l|r|}
\hline \multirow{2}{*}{ Responden } & \multicolumn{5}{|c|}{ Rangking } & \multirow{2}{*}{ T } \\
\cline { 2 - 6 } & 1 & 2 & 3 & 4 & 5 & 1 \\
\hline 1 & D & E & B & C & A & 0,6 \\
\hline 2 & D & B & E & A & C & 0 \\
\hline 3 & D & E & B & C & A & 1 \\
\hline 4 & D & B & E & C & A & 0,8 \\
\hline 5 & D & B & E & C & A & 0,8 \\
\hline 6 & D & E & B & A & C & 0,8 \\
\hline 7 & E & B & D & A & C & 0,4 \\
\hline 8 & D & E & B & C & A & 1 \\
\hline 9 & D & B & E & A & C & 0,6 \\
\hline 10 & D & B & E & C & A & 0,8 \\
\hline 11 & D & E & B & C & A & 1 \\
\hline 12 & D & B & E & C & A & 0,8 \\
\hline 13 & D & B & E & C & A & 0,8 \\
\hline 14 & D & B & E & A & C & 0,6 \\
\hline 15 & D & E & B & C & A & 1 \\
\hline 16 & D & B & E & C & A & 0,8 \\
\hline 17 & D & B & E & A & C & 0,6 \\
\hline 18 & D & E & B & A & C & 0,8 \\
\hline 19 & D & B & E & C & A & 0,8 \\
\hline 20 & D & E & B & A & C & 0,8 \\
\hline & & \multicolumn{2}{|c|}{ RATA-RATA } & 0,79 \\
\hline
\end{tabular}

Didapatkan rata rata Koefisien Korelasi Kendall Tau sebesar 0,79 atau 89,5\% dalam skala prosentase menandakan sistem secara baik mampu memberikan hasil yang sesuai dengan pengamatan manusia di dalam koleksi citra homogen.

\subsubsection{Pengujian dengan Koleksi Citra Heterogen}

Pengujian dengan koleksi citra heterogen bertujuan untuk mengetahui kemampuan sistem temu kembali dalam menemukan kembali citra yang benar mirip dalam koleksi citra yang berbeda beda jenis.

Tabel 7 Tabel Hasil Pengujian Sistem dengan Koleksi Citra Heterogen

\begin{tabular}{|c|c|c|c|c|c|}
\hline \multirow{2}{*}{ Query } & \multicolumn{5}{|c|}{ Rangking } \\
\cline { 2 - 6 } & 1 & 2 & 3 & 4 & 5 \\
\hline \multirow{2}{*}{$*$} & $\mathrm{C}$ & $\mathrm{D}$ & $\mathrm{E}$ & $\mathrm{A}$ & $\mathrm{B}$ \\
\hline & & & & & \\
\hline
\end{tabular}


Tabel 8 Tabel Hasil Responden dengan Koleksi Citra Homogen

\begin{tabular}{|l|c|c|c|c|c|r|}
\hline \multirow{2}{*}{ Responden } & \multicolumn{5}{|c|}{ Rangking } & \multirow{2}{*}{ T } \\
\cline { 2 - 6 } & 1 & 2 & 3 & 4 & 5 & 0 \\
\hline 1 & C & D & A & E & B & 0,8 \\
\hline 3 & C & D & B & A & E & 0,4 \\
\hline 4 & C & D & B & A & E & 0,4 \\
\hline 5 & C & D & B & A & E & 0,4 \\
\hline 6 & C & D & A & B & E & 0,6 \\
\hline 7 & C & D & A & E & B & 0,8 \\
\hline 8 & C & A & D & B & E & 0,4 \\
\hline 9 & C & D & A & B & E & 0,6 \\
\hline 10 & C & D & B & A & E & 0,4 \\
\hline 11 & A & C & D & B & E & 0,2 \\
\hline 12 & C & D & B & A & E & 0,4 \\
\hline 13 & A & C & D & E & B & 0,4 \\
\hline 14 & C & D & A & E & B & 0,8 \\
\hline 15 & C & A & D & B & E & 0,4 \\
\hline 16 & C & D & E & B & A & 0,8 \\
\hline 17 & C & D & A & E & B & 0,8 \\
\hline 18 & C & D & A & E & B & 0,8 \\
\hline 19 & C & D & A & B & E & 0,6 \\
\hline 20 & C & D & A & B & E & 0,6 \\
\hline \multicolumn{2}{|l|}{ C } & D & A & B & E & 0,6 \\
\hline
\end{tabular}

Didapatkan rata rata Koefisien Korelasi Kendall Tau sebesar 0,56 atau 78\% dalam skala prosentase menandakan sistem secara cukup baik mampu memberikan hasil yang sesuai dengan pengamatan manusia di dalam koleksi citra heterogen.

\section{Kesimpulan dan Saran \\ 5.1 Kesimpulan}

Dari semua uraian yang sudah dibahas dapat ditarik kesimpulan sebagai berikut:

1) Histogram warna fuzzy dapat dibentuk dengan merubah model warna dari citra, dari RGB menjadi HSL. Histogram warna fuzzy dapat digunakan dengan baik untuk merepresentasikan citra dalam suatu sistem temu kembali untuk menyederhanakan suatu histogram konvensional.

2) Formula chi square distance yang digunakan untuk menghitung uji kemiripan memberikan hasil yang reliable. Namun rumus ini tidak memberikan angka kemiripan namun menunjukkan angka perbedaan dari citra.

3) Pada proses pengujian sistem dapat diperoleh hasil antara lain:

a. Sistem mampu menemukan kembali citra yang sama

b. Sistem mampu menemukan kembali citra yang sama dari citra yang telah diperkecil

c. Sistem mampu menemukan kembali citra yang sama dari citra yang telah dibalik

d. Sistem mampu menemukan kembali citra yang sama dari citra yang telah dipotong e. Sistem mampu menemukan kembali citra yang mirip dalam koleksi citra yang homogen.

f. Sistem mampu menemukan kembali citra yang mirip dalam koleksi citra yang heterogen.

\subsection{Saran}

1) Sistem ini mengenali komposisi warna citra secara keseluruhan. Kedepannya diharapkan selain mengenali komposisi warna secara keseluruhan, sistem temu kembali ini dapat mengenali komposisi warna citra secara parsial.

2) Sistem temu kembali di penelitian ini hanya mampu mengenali citra melalui komposisi warna, diharapkan kedepannya sistem temu kembali ini dapat mengenali citra melalui tekstur atau bentuk obyek sehingga hasil temu kembali dapat lebih akurat.

\section{Daftar Pustaka:}

El-Feghi, Et all. 2007. Content-Based Image Retrieval Based on Efficient Fuzzy Color Signature,Canada: Electrical and Computer Engineering, University of Windsor.

Frediansah. dkk. 2012. "Sistem Temu Kembali Citra Berbasis Histogram Warna Fuzzy untuk Pencarian Citra Berwarna", Journal of informatics and Technology, Vol 1, No1: 130136.

Ford, A, and Roberts, A. 1998. Color Space Conversions [Online] http://poynton.com/PDFs/ coloureq.pdf [ 8 Januari 2015]

Kusumadewi, S. dan Purnomo, H. 2010. Aplikasi Logika Fuzzy, Untuk Pendukung Keputusan Edisi 2. Yogyakarta: Graha Ilmu.

Han, J and Ma, KK. 2002. Fuzzy Color Histogram andIts Use in Color Image Retrieval. IEEETransaction on Image Processing, vol. 11,no. 8.

Murti, B.1996. Penerapan Metode Statistik Non Parametrik Dalam Ilmu-ilmu Kesehatan. Jakarta: PT.Gramedia Pustaka Utama.

Putra, D.. 2010. Pengolahan Citra Digital. Yogyakarta: Penerbit Andi.

Sutoyo,T. 2009. Teori Pengolahan Citra Digital. Yogyakarta: Penerbit Andi.

Sabri, L. dan Hastono, SP. 2008. Statistik Kesehatan.Edisi Revisi. Jakarta: Rajawali Pers.

Siegel, S. 1992. Statistik Non Parametrik Untuk Ilmuilmu Sosial. Jakarta: PT.Gramedia Pustaka Utama.

Swandaru, A. dkk. 2013. "Sistem Temu Kembali Citra Berbasis Warna Menggunakan Transformasi Wavelet Haar dan Histogram Warna", Journal of informatics and Technology, Vol 2, No 3 : 77-91. 